\title{
An analysis of determinants of deposit money banks lending in Nigeria, 1990-2014
}

\author{
Biwet Mwanret Inusa \\ Department of Finance and Supplies, Bokkos Local Government Council, \\ Plateau State, Nigeria.
}

Correspondence author email: mbiwet@gmail.com

\begin{abstract}
Deposit money banks thrives on financial intermediation. Funds lending constitutes the largest income-earning asset in the portfolio of most deposit money banks generally. Hence, banks deploy huge resources to estimate, monitor and manage the quality of their loans and advances. This study aims at investigating the determinants of lending of deposit money banks in Nigeria. Secondary data was used to justify the relationship between commercial banks and lending in Nigeria. More so, the model used was estimated using Nigeria deposit money banks loans and advances (LOA) as dependent variable, and determinants (independent variables) such as volume of deposit (Vd), Interest rate (Ir), liquidity ratio (Lr) and annual average exchange rate (ExR) for the period of 1990 - 2014 (25 years). The techniques used in this investigation were : Augmented Dickey-fuller (ADF) test), multiple regression analysis and Granger causality test. The estimated result revealed that there is a positive relationship between loans and advances and volume of deposit and annual average exchange rate of Naira to dollar, while interest rate and liquidity ratio has a negative relation: all conform to the approri expectation. The study then suggests that commercial banks should focus on mobilizing more deposits as this will enhance their lending performance, and should formulate critical, realistic and functional plans that will ensure its profitability, liquidity and solvency. The government should ensure it uses monetary policy such that will create enabling environment for the deposit money banks to generate more deposits so as to channel it to investors for investment.
\end{abstract}

Keywords: Determinants, Deposit money banks, Lending, Nigeria

JEL Classification: G21

\section{INTRODUCTION}

Right from the time of evolution of money in the human society, there has been those who possess money in excess of their immediate needs i.e. surplus spending units and those whose current possession cannot finance their economic activities i.e. the deficit spending units. The realization by the surplus spending units that their excess can be used beneficially to meet the shortfalls experienced by the deficit spending units led to the introduction of a credit system. This system was initially characterized by lenders (surplus spending units) and borrowers (deficit spending units) having to search out themselves and deal directly, i.e. direct financing (Akpam, 2009 as cited in Olusanya Oyebo Ohadabere 2012, Akpanko and Acha, 2010), while indirect financing includes the 
aggregation of deposits from various household, firms and government by commercial banks for lending to the deficit spending units.

The practice of lending by deposit money banks undoubtedly constitute the fulcrum of their operations and businesses, this implies that lending administration and management require considerable expertise and deftness on the part of the bank management teams. Basically, deposit money banks are normally irreversibly committed to compensate depositors on their funds (deposits). Therefore, they are under operational obligations to determine appropriate avenues where deposit funds could be placed to generate reasonable returns, while striving to maintain liquidity through proactive lending policies (Adedoyin and Sobodum, 1996).

Commercial banks are the most important savings, mobilization and financial resource allocation institutions. Consequently, these roles make them an important phenomenon in economic growth and development. In performing this role, it must be realized that banks have the potential, scope and prospects for mobilizing financial resources and allocating them to productive investments. Therefore, no matter the sources of the generation of income or the economic policies of the country, commercial banks would be interested in giving out loans and advances to their numerous customers bearing in mind, the three principles guiding their operations which are, profitability, liquidity and solvency.

However, commercial banks decisions to lend out loans are influenced by a lot of factors such as the prevailing interest rate, the volume of deposits, the level of their domestic and foreign investment, banks liquidity ratio, prestige and public recognition to mention a few.

Furthermore, commercial banks by its nature is highly prone to volatility and fragility, arising from exogenous shocks in the economy, policy measures by regulatory authorities and it is therefore, more often than not subjected to regulations and supervisions. The guidelines embrace statutory regulations that are imposed externally. One of such guidelines is the provision of Banks and other financial Institution Act (BOFIA) as amended which restricts the terms and amount of loan that a bank can grant to its insiders (Oloyede 1999).

The ability of commercial banks to ensure its liquidity and survival, will contribute towards promoting growth and development of the economy and this depends on their effective handling of lending operations. This requires that transactions on loan and advances are carried out with trust and confidence devoid of or at minimal lending risks. The required safe and sound bank lending practices involves taking into cognisance the regulatory requirements and the internationally entrenched factors affecting loan and advances (John, 1995).

Itune (1983) posited that a bank's ability to grant loans and advances is checked by the availability of cash in its vault. The demands by customers in terms of withdrawals from their deposits have to be met instantaneously. Commercial banks, therefore have to stock reasonable quantity of cash to meet customers' demands. Hence a commercial bank cannot afford to grant loan and advances in excess of its cashing ability, thus, the issue of liquidity in banking operations also affects the lending behaviour of commercial banks.

The main objective of this study is to investigate the main factors that influence lending of deposit money banks in the country i.e. to appraise the factors that determine lending of deposit money banks generally in the economy. By implication, this will aid the relevant regulatory authorities and policy makers in formulating appropriate policies that will enhance effective administration and management of loans, credits and other forms of lending by deposit money banks in the economy. 
Banking activities majorly include the act of lending which is the fulcrum of deposit money banks. The world over, the operations of deposit money banks are regulated exogenously by supervisory authorities such as the apex bank, deposit insurance institutions and so on, and also endogenously by their boards of directors. Therefore, the lending activities of deposit money banks are regulated by both regulatory authorities and the board of directors of the various banks.

Consequently, it is obvious that some of the factors or determinants of lending by deposit money banks are subjected to the dictates of their directors, where control and manipulations are done within the organisations, whereas, the other determinants are outside their control, that is, exogenous to the banks.

While there are empirical studies on the determinants of lending of deposit money banks in the advanced economies, there has been only a few studies on lending of deposit money banks in developing economies such as Nigeria.

Nigeria being a mono-cultural economy that relies almost entirely on revenue generated from oil for its sustenance, and with the effort from the incumbent government to diversify into other areas, more specifically agriculture and mining, it is obvious that it does not have the financial muscle to do that all alone. Therefore, the deposit money banks will have to be engaged so as to avail loans and advances to investors in order that success is achieved.

However, as mentioned surpra, some factors can impede lending to the investors (e.g. volume of deposit, liquidity ratio, interest rate, exchange rate e.t.c.), as such the government will have to make effort towards proving enabling environment for the deposit money banks to thrive, and subsequently the economy at large.

\section{LITERATURE AND EMPIRICAL REVIEW}

\section{Literature review}

A lot of studies have been carried out in this area in an attempt to determining the factors responsible or that affect commercial bank lending within the Nigeria environment. Most studies divide the determinants of commercial banks lending into two (2) broad categories: Internal and External factors. The internal factors (endogenous) constitute: Profitability which is directly under the control of the bank management, and external factors which are not within the control of the bank management (exogenous factors) e.g. money supply, inflation, competition, regulations, market share, exchange rate e.t.c.

A lot has been written in terms of lending activities of various commercial banks. In the opinion of Nwanko (2000), "Credit constitute the largest simple income earning asset in the portfolio of most banks. This explains why banks spends enormous resources to estimate, monitor and manage credit quality." This can be seen to be a great and critical factor to be considered in assessing the determining factors of banks lending in Nigeria as huge sums of money is involve.

Chodechai (2004), while digging deep into the factors that affect and influence interest rates, degree of lending volume and collateral setting in loans and advances decision stated that, "banks have to be careful with their pricing decisions as regard to lending as banks cannot charge loan rates that is too low, because the revenue from the interest income will not be able to cover the cost of deposits, general expenses and the loss of revenue from some borrowers that do not pay, and also, charging too high loan rates may also create an advance selection situation and moral hazard problems for the borrowers." 
According to Adedoyin and Sobodum (1991), "lending is undoubtedly the heart of banking business. Therefore, its administration requires considerable skills and dexterity on the part of the bank management."

Osayaneh, (1996) further stated that "the major objective of commercial banks' lending is to maximize profit". Ojo, (1999), in his investigation of the role and failure of financial intermediation by banks in Nigeria revealed that "commercial banks can lend on medium and short-term basis without necessarily jeopardising their liquidity if they must contribute meaningfully to the economic development, and the maturity pattern of their loans should be on a long-term nature rather than of a short-term period."

Chizea (1994), affirm that "there are certain aspects of fiscal and monetary policies which could affect the decision of the discerning and informed public to patronize the bank, and the lending function of commercial banks. Paramount amongst these measures is what could be called the interest rate disincentive." It is obvious that as inflation increase, the purchasing power of money lodged in deposit account reduces to the extent that savers per force pay an inflation tax. There is also the fear that a hike in interest rate will increase inflation rates and make a negative impact on the rate of investment.

Usman (1999), in a treatise in bank regulation and supervision in Nigeria, posited that the factors that affect commercial banks' lending depend on the choice of certain policy instruments in their banking operations. Such policies instruments (Usman, 1999) include a rigidly administered interest rate structure, direct credit, unremunerated reserve requirements and stabilizing liquidity control measures like the stabilization securities. Furthermore, Usman (1999), observed that "a major regulation affecting commercial banks' lending in Nigeria is the restriction on the amount of interest banks are allowed to pay on deposits which in turn affects their efforts to attract reasonable volume of deposits, the interest they charge on their loans and advances and the liquidity ratio as fixed by the CBN."

\section{Empirical review}

Felicia (2011), used regression analysis to investigate the determinants of commercial banks lending in Nigeria. The study discovered that commercial banks deposits have the greatest impacts on their lending.

Adofu and Audu (2010), used ordinary least square method to ascertain the assessment of the effects of interest rate deregulation in enhancing agricultural productivity in Nigeria. The study found out that interest rate play a significant role in enhancing economic activities.

Rasheed (2010), used error correction model (ECM) to investigate interest rates determination in Nigeria. The study found out that as the Nigerian financial sector integrates more with global markets, returns on foreign assets will play a significant role in the determination of domestic interest rates.

Achah (2011), probed into "the effect of banks financial intermediation in economic growth" in time frame of 1980-2008, adopting the Grandger causality test to ascertain the relationship that exist between savings mobilization and credit on one side, and economic growth on the other. Acha's study could not identify any significant casual relationship between the variables.

Ajayi (2007) in his study investigated some major determinants of loan and advances in the Nigerian financial system. He used explanatory variables such as liquidity ratio, capital base, bank deposit and lending rates to determine their effect on loans and advances. The study discovered an existing relationship between dependent variable (bank loan and advances), and independent variables of total deposit, capital based, liquidity ratio and lending rate.

Therefore, this research work was conducted to appraise the determinants of deposit money banks lending in Nigeria, so that the government is able to create the enabling 
environment for the banks in order that it makes loans and advances accessible to investors in the country.

\section{HYPOTHESES}

The main issues in this study were synthesized into the following hypotheses:

\section{Hypothesis 1}

Ho: There is no significant relationship between banks' loan and advances and volume of deposit in Nigeria.

Hi: There is a significant relationship between banks' loan and advances and volume of deposit in Nigeria.

\section{Hypothesis 2}

Ho: There is no significant relationship between banks' loans and advances, and interest rate in Nigeria.

Hi: There is a significant relationship between banks' loan and advances, and interest rate in Nigeria.

\section{Hypothesis 3}

Ho: There is no significant relationship between banks' loans and advances and liquidity ratio in Nigeria.

Hi: There is a significant relationship between banks' loan and advances and liquidity ratio in Nigeria.

\section{Hypothesis 4}

Ho: There is no significant relationship between banks' loans and advances and exchange rate in Nigeria.

Hi: There is a significant relationship between banks' loan and advances and exchange rate in Nigeria.

The methodology used to test the hypotheses mentioned above are: Augmented Dickey-Fuller unit root test which was used to ascertain the level of stationarity of the variables in question; Granger causality test to help identify if at all there is any causal relationship between the variables used, and finally, the ordinary least square test which was used to identify the type of relationship that exist between and among the variables.

\section{THEORITICAL FRAMEWORK}

\section{Loan pricing theory}

This theory has it that banks cannot always set high interest rates by trying to earn maximum interest income. Banks should consider the problems of adverse selection and moral hazard since it is very difficult to forecast the borrower type at the start of banking relationship (Stiglitz and Welss, 1981).

\section{Credit market theory}

This is a model of the Neoclassical credit market, it has it that the terms of credit clear the market. If collateral and other restrictive (covenants) remain constant, the interest rate remains the only price mechanism. With an increasing demand for credit and a given customer supply, the interest rate rises and vice versa. It is thus belief that the higher the failure risk of the borrower, the higher the interest problem (Ewert, Szczesmy, and Schenk 2000).

\section{The signalling arguments}

The signaling argument states that good companies should provide more collateral so that they can signal to the bank they are less-risky type of borrowers such that they are then charged lower interest rates. Meanwhile, the reverse signaling argument states that 
banks only require collateral and or covenants for relatively risky firms that also pay higher interest rates (Chodechai, 2004; Ewert and Schenk, 1998).

\section{Theory of multiple lending}

This theory states that banks would be less inclined to share lending (loan syndication) in the presence of well-developed equity markets and after a process consolidation. Both outside equity and mergers and acquisitions increase banks' lending capacity, thus reducing their need of greater diversification and monitoring through share lending. (Carletle Cerasi, and Daltung 2006)

\section{Conceptual frame-work}

Financial intermediaries are organisations that are inherently known with the function of financial intermediation: They mobilize funds or deposits from surplus spenders for lending to deficit spenders, mostly for investment purposes, which is expected to have a positive impact on the economic growth and development of a country. Business organizations can obtain the money or capital they need to buy capital goods and other things needed, such as machinery and equipment only if the necessary institutions, instruments and procedures have been established for making savings available for such investments (Ekezie 2006).

Generally, monetary policy also affects banks assets which arises because of their lending (loans) as well as banks' liabilities (deposits). The implication of operations of policy is that besides shifting the supply of deposits, it also shifts the supply of bank loans. For instance, an expansionary monetary policy that increase bank reserves and bank deposits increase the quantity of bank loans available. The crucial response of banks to monetary policy is their lending response.

\section{METHOD AND PROCEDURE}

\section{Source of data}

The sample analyzed in this paper consist of secondary data collected from 2014 statistical Bulletin of the central Bank of Nigeria (CBN) from the year 1990-2014, that is, a period of 25 years.

\section{Model specification}

This analysis is to determine whether Vd, Lr, Ir and ExR have influence or affects the behaviour of deposit money banks in giving out loans and advances to the public or investors. Unit root test, multiple regression analysis, and Granger causality tests were employed.

$$
\mathrm{LOA}=\mathrm{f}(\mathrm{Vd}, \mathrm{Ir}, \mathrm{Lr}, \mathrm{ExR}, \mathrm{U})
$$

The explicit form of equation (i) above is shown as follows:

$\begin{array}{lll}\text { LOA } & : & \text { Loans and Advances } \\ \mathrm{Vd} & : & \text { Volume of deposit } \\ \mathrm{Ir} & : & \text { Interest rate } \\ \mathrm{Lr} & : & \text { Liquidity ratio } \\ \mathrm{ExR} & : & \text { Exchange rate } \\ \mathrm{U} & : & \text { Disturbance term }\end{array}$

The model is thus formulated as:

$$
\mathrm{Y}=\mathrm{b}_{0}+\mathrm{b}_{1} \mathrm{Vd}+\mathrm{b}_{2} \mathrm{Ir}+\mathrm{b}_{3} \mathrm{Lr}+\mathrm{b}_{4} \mathrm{ExR}+\mathrm{U}
$$

The approri expectation is $\mathrm{Vd}, \mathrm{ExR}>0$ and $\mathrm{Ir}, \mathrm{Lr}<0$ 


\section{RESULT AND DISCUSSION}

The time series data used in this research work was obtained from the statistical bulletin of the Central Bank of Nigeria (CBN), Central Bank Annual Reports, publications, and National Bureau of Statistics (NBS) of Nigeria.

\section{Unit root test (ADF)}

The result in Table 1 shows that Loans and advances (LOA) and interest rate (Ir) are stationary at first difference, that is, the variables are I(1) series, while Volume of deposits $(\mathrm{Vd})$, Liquidity Ratio (Lr), Exchange rate (ExR) are stationary at levels meaning they are $\mathrm{I}(0)$ series. This is deducted from the fact that for the levels of variables, the absolute values of the ADF statistics are greater than the critical values of the ADF at 5\% level of significance or their probabilities are all less than $5 \%$.

Table 1. Augmented dickey-fuller (ADF) unit root test result

\begin{tabular}{lccc}
\hline Variables & ADF T- Statistics & Order of integration & Prob. \\
\hline LOA & -3.811380 & $\mathrm{I}(1)^{* *}$ & 0.0123 \\
Vd & 3.887684 & $\mathrm{I}(0)^{*}$ & 1.0000 \\
Ir & -6.601740 & $\mathrm{I}(1)^{*}$ & 0.0001 \\
Lr & -3.509385 & $\mathrm{I}(0)^{* *}$ & 0.0201 \\
ExR & -5.333662 & $\mathrm{I}(0)^{*}$ & 0.0005 \\
\hline
\end{tabular}

Note that $* * *)$ denotes $5 \%$ and $1 \%$ levels of significance respectively.

\section{Multiple regression test}

The OLS is a method used to estimate the relationship between variables. Mason (1996) states that regression analysis is a technique for developing or modeling several variables into a linear equation, and later used for prediction or forecasting. It is used to determine the degree of association and the explanatory power of the independent variables on the dependent variable, and to determine the statistical significance of the coefficient of the variables. The choice of the OLS technique for the study is because of its Best Linear Unbiased Estimator (BLUE) properties (Gujarati, 2004).

The estimate of the model formulated is reported in Table 2. The result equally shows that there is direct (positive) relationship between deposit money banks' loans and advances and volume of deposit, that is, as the volume of deposit of commercial banks increases, it leads to an increase in loan and advances, at the same time as people realise the prospects of accessing such loans and advances, they equally increase their volume of deposit so as to be able to access it when needed and vice versa. Moreover, the coefficient of the parameter volume of deposit $(\mathrm{Vd})$ is 0.633 and it indicates that $1 \%$ increase in $\mathrm{Vd}$ in commercial banks will lead to $0.633 \%$ increase in loans and advances (LOA). Moreover, the sign of $\mathrm{Vd}$ conform to our approri expectation and this shows that as $\mathrm{Vd}$ increases, commercial banks' LOA equally increase. Also, the t-statistics for parameter $\mathrm{Vd}$ shows that it is statistically significant at 5\% level of significance.

Furthermore, it was discovered from the result that there is a negative or inverse relationship between commercial bank LOA and the lending rate (Ir), that is, as the Ir increase it leads to a decrease in commercial banks' LOA vice versa. However, the coefficient of Ir is -74.567 which goes to say that a $1 \%$ increase in Ir will lead to $74.567 \%$ decrease in LOA, moreover, the sign of Ir confirm with the approri expectation. Also, the t-statistics for parameter Ir shows that it is negatively statistically significant at $5 \%$ level of significance. 
Table 2. Results of regression computation

\begin{tabular}{|c|c|c|c|}
\hline \multicolumn{4}{|c|}{ Dependent Variable: LOA } \\
\hline Method: $\quad$ Least $\mathrm{S}$ & \multicolumn{3}{|c|}{ Least Squares } \\
\hline Sample : $\quad 1990-$ & \multicolumn{3}{|c|}{$1990-2014$} \\
\hline \multicolumn{4}{|c|}{ Included observations: 25} \\
\hline Variables & Coefficients & Standard Error & T-Statistics \\
\hline $\mathrm{C}$ & 4352.056 & 3029.624 & 1.437 \\
\hline $\mathrm{Vd}$ & 0.633 & 0.151 & 4.207 \\
\hline Ir & -74.567 & 107.690 & -0.692 \\
\hline $\mathrm{Lr}$ & -77.020 & 38.731 & -1.989 \\
\hline ExR & 19.977 & 8.352 & 2.392 \\
\hline R-Square & : & 0.840 & \\
\hline Adjusted R-regression & : & 0.808 & \\
\hline S. E of regression & : & 1.588146 & \\
\hline F- Statistics & : & 26.185 & \\
\hline DW-Statistic & : & 2.266 & \\
\hline T-table value & & F-table value & \\
\hline
\end{tabular}

More so, it was realized that there is an inverse relationship between deposit money banks LOA and liquidity ratio (Lr), that is, as the liquidity ratio increases, the deposit money banks LOA decreases vice versa. However, it can be seen that the coefficient of the parameter $\mathrm{Lr}$ is -77.020 which means that a 1\%increase in Lr will lead to $77.020 \%$ decrease in deposit money banks LOA. Besides, the negative sign it carries conform to the approri expectation. Again that t-statistics for parameter Lr shows it is statistically insignificant.

Annual Average Exchange Rate (ExR) from table 2 above, has a positive and a direct relationship with commercial banks' LOA, that is, as ExR increase in favour of the naira, the deposit money banks LOA also rise, because people increasingly invest in export for profit, vice versa. Also the coefficient of the parameter ExR is $19.977 \%$ meaning that $1 \%$ increase in ExR leads to $19.977 \%$ increase in LOA of deposit money banks in Nigeria. Besides, the sign carried by the parameter estimate ExR (positive) conforms to the approri expectation. Also, the t-statistics of the parameters ExR shows that it is statistically significant at $5 \%$ level of significance.

Finally, the F-statistics shows that the overall parameters/model is statistically significant at 5\% level of significance, and the R-square being 0.840 means that $84 \%$ variation in the dependent variable has been explained by the independent variables $(\mathrm{Vd}$, Ir, Lr, ExR), while the remaining 16\% are exogenously determined from the model.

Therefore, from our empirical results done thus far, we reject the null hypothesis $\left(\mathrm{H}_{\mathrm{o}}\right)$ and accept the alternative hypothesis $\left(\mathrm{H}_{1}\right)$, and conclude that there is a functional relationship between the dependent variable (banks' loan and advances), and the specified number of independent variables (volume of deposit, interest rate, liquidity ratio and exchange rate) in Nigeria.

\section{Granger causality test}

From the causality test result in Table 3 , it revealed that there is a bi-directional causality running from $\mathrm{Vd}$ to LOA and LOA to $\mathrm{Vd}$ (i.e. Vd granger cause LOA, and LOA equally granger cause $\mathrm{Vd}$ ), However, the result shows that there is no causal relationship between Ir and LOA. Again, we can see from the result that there is a uni-directional causality running from LOA to Lr (i.e. LOA granger cause Lr). Finally, the result shows that there is no causality relationship between LOA and ExR. 
Table 3. Granger causality tests result

Sample: 19952014

Lags: 2

\begin{tabular}{lccc}
\hline Null Hypothesis: & Obs & F-Statistic & Prob. \\
\hline VD does not Granger Cause LOA & 18 & 9.04846 & 0.0035 \\
LOA does not Granger Cause VD & & 17.4484 & 0.0002 \\
\hline IR does not Granger Cause LOA & 18 & 0.42361 & 0.6634 \\
LOA does not Granger Cause Ir & & 0.89330 & 0.4330 \\
\hline LR does not Granger Cause LOA & 18 & 1.44407 & 0.2714 \\
LOA does not Granger Cause Lr & & 16.0849 & 0.0003 \\
\hline EXR does not Granger Cause LOA & 18 & 0.88741 & 0.4352 \\
LOA does not Granger Cause ExR & & 0.01356 & 0.9865 \\
\hline
\end{tabular}

\section{CONCLUSION AND RECOMMENDATIONS}

\section{Conclusion}

Commercial banks remain dominant in the banking system in terms of their shares of title assets and deposit liabilities. Their total loan and advances, a major component of total credits to the private sector are still on the increase in spite of the major constraints posted by the government regulations, institutional constraints and other macroeconomic factors. However, both government and commercial banks should be mindful of the fact that the environments in which they operate are important factors in the bank performance and behavior. Where the environment is conducive and supportive, performance is enhanced and good lending guaranteed, but where the environment is unstable and harsh, the bank's performance suffers.

The implication of this is that a change in the independent variables will have a great impact on banks' loans and advances with Vd and ExR having a positive or direct relationship with LOA, while Ir and Lr have a negative or inverse relationship with LOA of deposit money banks in Nigeria.

\section{Recommendation}

Based on the findings of this study, it was recommended and considered important that deposit money banks in Nigeria build a system and skills in liquidity management, assets and liability management to ensure efficacy. There should be closer consultation and cooperation between commercial banks and the regulatory authorities, so that the effect of regulatory measures on commercial banks is taken into consideration at the state of policy formulation. The cost associated with lending to priority sectors as a national goal should be taken care of by the entire society through the government budget instead of burdening the commercial banks with such cost. This is necessary because the commercial banks cannot afford to overprice or under price their loans for efficient lending performance. Banks should try as much as possible to strike a balance in their loan pricing decisions, this will help them to be able to cover cost associated with lending and at the same time maintain good banking relationship with their borrowers. Commercial banks should strategise on how to attract and retain more deposits so as to further improve on their lending performance.

\section{REFERENCES}

Acha, G. (2011). Does bank financial intermediation cause growth in developing Economies, the Nigerian Experience, Interbond business and Management, 3 (1), 156-161. www.academia.edu/26683568. DOI 10.3968

Adedoyin and Shobodun, (1991). Lending in Banking Business, Problems and Prospect,3rd edition, pg 23-34, Saiye Printers, Lagos

Adedoyin, and Sobodun, (1996), Commercial Banks Lending Activities in Nigeria, Nigerian Financial Review, 9(3), 36-37. 
Ajayi, D. (1978). Deposit Rates in a deregulated Regime and its implications, 3, pg 5567, University Press limited.

BOFIA, (1998). Requirement for Investment and Lending behavior in Nigeria banking industry. www.cbn.gov.ng/out/publications/bsd

Carletti, E., Cerasi, V. and Daltung, S. (2006), Multiple-Bank Lending: Diversification and Free-riding in Monitoring, Working Paper, Department of Statistics: Universita degli Studi di Milano-Bicocca,. https://ideas.repec.org/a/eee/jfinin/v16y2007i3p425-451.html

Chizea, B. (1994), Finance for Farming: A Guide to the Lending Banker; Lagos: Institute of Banker, Nigeria.

Chodechai, S. (2004), Determinants of Bank Lending in Thailand: An Empirical Examination for the years 1992 - 1996, Unpublished Thesis.

Ekezie, E. S. (2006).The Elements of Banking, Onitsha,Nigeria: Africana First Publishers Limited.

Ewert, R. and Schenk, G. (1998), Determinants of Bank Lending Performance, Working Paper, Center for Financial Studies, University of Frankfurt. https://econpapers.repec.org/RePEc:zbw:cfswop:199806

Ewert, R., Szczesmy, A. and Schenk, G. (2000), Determinants of Bank Lending Performance in Germany ,Schmalenbach Business Review (SBR), 52, 344 362. https://www.researchgate.net/publication/24049864

Goldfield, M. and Chandler, L. (1986), The Economics of Money and Banking, 9th edition, NewYork: Harper and Row Publishers.

Gujarati, D. N. (2004). Basic Econometrics, 4th ed, New York: McGraw-Hill companies.

Ituwe, T. (1983) Elements of practical Banking, a textbook 2nd edition, Ibadan, University Press

Jhingan, M. L. (2008). Money, Banking, International Trade and Public Finance, 7th Edition, Delhi:Vrinda Publications (P) Ltd.

John, P.O. (1998), A Practical Guide to Bank Lending and Administration, Lagos: Du Prince and Pal.

Mason, J. (1996). Qualitative researching. Second edition, University of Manchester.

Nwankwo, G. O. (2000), Organizing for Financial Risk Management, The Credit Administrator, 2(2), 32-39. https://www.coursehero.com/file/p1a66n4/

Ojo, J. A. T. (1999), Roles and Failures of Financial Intermediation by Banks, CBN Bullion, 23(3),10-12.

Olokoyo, F. O. (2011). Determinants of Commercial Banks' Lending Behavior in Nigeria, International Journal of Financial Research 2(2),July, 61-72. Retrieved on 21 February, 2013.(www.sciedu.ca/ijfr)

Olusanya,S. O., Oyebo, A. O. Ohadebery, E. C., (2012).Determinants of Lending Behavior of Commercial Banks: Evidence from Nigeria, A co-integration Analysis(1975-2010). Journal of Humanities and Social science, 5,Nov.Dec.,77-80.

Oloyede, B. (1999), Principles of Money and Banking, Ado: Forthright Educational Publishers.

Osayameh, R. (1996), Practice of Banking: Lending and Finance, 2, Lagos: F.A. Publishers.

Peek, J. and Rosengren, E. S. (1995), Bank Regulation and the Credit Crunch. Journal of Banking and Finance, 679-692. http://www.sciencedirect.com/science/article/pii/0378-4266(94)00148-v

Stiglitz and Weiss (1991). Analysis of Loan and disbursement in the Commercial Bank, 2nd edition, Macgraw Hill Publication limited.Uhomoibhi

Usman, S. (1999, Jan- March), Bank Regulation and Supervision in Nigeria, The Nigerian Banker, 7-9 